\section{Personal Integrity within Society}

\section{Ana-Maria DASCĂLU1}

${ }^{1} \mathrm{MA}$, Faculty of Law and Administrative Sciences, "Ştefan cel Mare" University from Suceava, Romania.
Abstract: In the most general sense, integrity is a concept that can only be understood in relation to another. The Latin "integritas", from which the word "integrity" is derived, refers to the indefinite and irreproachable, untouched condition of an object. Initially, it was used to describe the indeterminate power of the body, but also the chastity or purity of a person, in opposition to an unclean character. Of course, the term can be used with respect to anyone or anything, who/that can have integrity, as long as they/it are intact or untouched. Anyone or anything who has retained their natural characteristics can be regarded as integral. Anyone who is morally weaker in comparison with previous state has lost his integrity. Thus, if we consider this explanation, it can be observed, on closer examination, that this meaning of integrity has a very strong normative connotation because it implies an ideal, a standard from which any rambling is not only a transgression, but an aberration that leads in a worse state. However, there is no measurement system for any object or person that clearly indicates loss of integrity. Not every change means a loss and not every violation represents a loss of integrity. Some changes do not endanger physical or spiritual integrity, because, if they were, no form of life would be integral, because life involves changes and, often, these changes can be seen as real disturbances, but normal from an evolutionary point of view.

Keywords: the moral value of integrity; personal integrity; social integrity.

How to cite: Dascălu, A.-M. (2019). Personal Integrity within Society. Journal for Ethics in Social Studies, 3(1), 16-21. doi: $10.18662 /$ jess.18 


\section{Aspecte introductive}

Unde anume şi ce anume reprezintă graniţa care separă lipsa de integritate de evoluție atunci când discutăm de schimbare depinde în primul rând de obiect sau de persoana în cauză, precum şi de condiţia sa ideală. În orice caz, este nevoie de un punct de referinţă care să ateste condiția sau starea naturală, care să fie punctul zero al integrității indiferent de perspectivă, fizică sau spirituală. În ceea ce priveşte acest etalon, există două posibilități care să sprijine o evaluare: în primul caz, subiectul depinde doar de el însuşi, apelând la abilitățile intrisece pentru a determina dacă este sau nu integru. În acest caz, se poate observa că punctul de referință ne este impus de către privitor sau de obiectul ori persoana în cauză.

În al doilea caz, punctul de referință nu este deja impus prin natura lucrului sau a persoanei analizate. Această posibilitate se aplică în cazul „noului” deoarece, odată ce nu ştim cum ar trebui să fie, nu putem face presupuneri asupra integrităţii unei acțiuni sau a unui lucru.

Conceptul de integritate rămâne un concept deschis, deoarece înțelesul său poate fi atribuit mai multor tipuri de integritate, definite de puncte distincte de referință, însă în această lucrare ne vom concentra asupra integrităţii personale. Integritatea personală se referă la modul în care un individ este loial unor valori individuale, autoimpuse, în timp ce integritatea morală descrie aderenţa la un set de principii şi valori considerate morale. Bineînțeles, acestea se pot suprapune, deoarece valorile morale dintr-o societate pot deveni valori personale.

\section{Privire filosofică asupra integrității personale}

O încercare de a defini integritatea poate să aibă în vedere etimologia cuvântului, care provine din latinescul ,integritas”, care inseamnă unitate sau plenitudine. Acest aspect arată faptul ca integritatea presupune în primul rând ca o persoană sau un grup de persoane să introducă în mod armonios diferite părți ale gândirii comune într-o unitate deja existentă. La o primă vedere, integritatea poate fi văzută ca o lipsă de contradicții, însă, în acelaşi timp, nu se poate vorbi de acest concept dacă nu există un conflict între ceea ce este şi ceea ce ar trebui să fie.

În viata de zi cu zi, termenul „integritate” este folosit în comparație cu propria persoană, în sensul de integritate personală, iar în această lucrare vom dezvolta şi vom încerca să definim acest concept.

Indivizii pot avea grade diferite de integritate. O persoană integră nu poate fi mituită, este onestă, spune mereu adevărul, spune ceea ce gândeşte şi 
acţionează în conformitate cu cele enunţate. Un individ integru este demn de încredere, deoarece sinele aparent este concordant cu sinele intim. În societate, integritatea este o valoare ridicată la rang de virtute, dar particularitatea acesteia este că diferă de la persoană la persoană, atât timp cât nu există un set de principii exhaustive şi stabile pentru toate grupurile sociale în funcție de care să se aprecieze în mod absolut ce este integru şi ce nu.

Filosofia a încercat, de-a lungul timpului, să clarifice conceptul de integritate personală prin diferite metode. Integritatea persoanală reprezintă organizarea dorințelor, a devotamentului, a valorilor şi acțiunilor în aşa fel încât să nu existe conflict între acestea. Astfel, un individ este integru dacă diferitele aspecte care alcătuiesc sinele sunt integrate pe deplin. Integritatea devine abilitatea de a menține sinele intact în concordanță cu viața, pe deplin integrate una în cealaltă. Pentru a manifesta o asemenea trăsătură, individul trebuie să fie rațional în mai multe aspecte ale vieții, să fie consistent în comportametul său, pentru a nu fi judecat ca influențabil, să nu acționeze decât în baza unor dovezi şi argumente logice etc.

O altă viziune filosofică pune accentul pe păstrarea identității. Astfel, o persoană este integră dacă posedă anumite principii sau valori care sunt atât de importante încât nu există acțiune care să nu aibă la bază ideile respective, chiar şi în cele mai adverse condiții, pentru că renunţarea la acestea ar echivala cu renunţarea la esența sinelui. Având în vedere aceste aspecte, se poate afirma că integritatea personală se suprapune peste integritatea morală, însă nu complet, deoarece integritatea personală nu impune existența unor valori morale.

Persoana care interacționează cu un anumit grup social, în cadrul căreia sunt menținute anumite valori, nu poate fi integră pentru grupul respectiv decât dacă introduce în sistemul său de valori şi principii pe cele ale grupului, acționând în aşa fel încât să nu contravină acestor norme. Totdată, pe lângă aderarea sinelui la principiile grupului, pentru a fi considerat integrat, individul social trebuie să îşi îndrepte energia către un scop valorizat de grup. Cu alte cuvinte, persoana socială nu se concentrează doar pe sine, ci are în vedere şi interesul celorlalţi indivizi (Calhoun, 1995). In cadrul interacțiunii sociale, o persoană îşi respectă propria logică, dar este în acelaşi timp conştientă de propriile limite şi conştientizează că şi ceilalţi acţionează conform rațiunii lor. Astfel, persoana integră dintr-o societate nu echivalează cu un fanatic incapabil de a admite propriile greşeli. 


\section{Definirea integrității personale}

Abordările privind integritatea personală sunt diferite în funcție de cine face interpretarea, astfel încât este puțin probabil că integritatea personală să aibă acelaşi înțeles pentru orice individ (Apostu, 2016). Din moment ce integritatea personală este influențată de viziunea personală a celui căruia i se atribuie, este firesc să nu ne limităm la un singur înțeles. Intreaga discuție despre integritate ar trebui să aibă în vedere şi condiția umană, în forma sa ideală şi onorabilă. Integritatea nu este un aspect normativ obiectiv, ci implică şi subiectivitatea individului care îşi defineşte condiția ideală de om. Astfel, integritatea unei persoane nu poate fi deplină în abstract şi identică cu integritatea altei persoane, deoarece niciodată nu vor exista doi oameni care să aibă în mod identic aceleaşi valori. Integritatea se apreciază în funcție de cel care o evaluează şi de similitudinea dintre principiile sale şi ale celui evaluat.

Un exemplu extrem de pertinent care să susțină argumentul prezentat mai sus derivă din Biblie. Astfel, în Vechiul Testament, omul, pentru a fi considerat integru de Dumnezeu trebuia să respecte cele zece porunci scrise de însuşi Dumnezeu pe cele zece table predate lui Moise pe muntele Sinai. Pe lângă cele zece porunci, care reprezintă o variantă generalizată a unor norme morale în general comune oricărei societăți, lui Moise i-au fost transmise prin inspirație divină diferite ritualuri caracteristice diverselor comportamente ale unui iudeu. Este de menționat faptul că valoarea acordată acestor comportamente (mai ales ale celor care sancționează lipsa de integritate, cum ar fi lapidarea) s-a schimbat în Noul Testament, când integritatea a început să fie evaluată conform învăţăturilor lui Hristos, care revine asupra unora dintre aceste ceremonii.

Integritatea personală trebuie să fie tratată ca un concept complex, compus din mai multe valori, dintre care unele se suprapun parţial. Integritatea personală devine astfel un termen de maximă generalitate, din care se desprind multe alte calități umane cu rol de virtute care, la rândul lor, pot face parte din integritatea intelectuală, integritatea artistică, integritatea profesională, ce intră sub incidența integrității personale, dar nu o conturează în totalitate. Locke (1996) pune în discuție condiția ideală a omului, a cărui acțiuni sunt inteligibile în funcţie de timpul şi de loculul la care ne raportăm, dar şi de o anumită condiţie ideală a omului, care depăşeşte barierele spaţiutimp, această condiție fiind specifică persoanei care, prin acțiunile sale, nu disturbă continuitatea şi armonia societăţiii. 


\section{Integritatea raportată la condițiile socio-politice în care se află individul}

În multe dintre cazuri, punctul de referință în funcție de care se evaluează integritatea personală este adjudecat din exterior, fiind deseori legat de un set de valori sau de un anumit scop pe care trebuie să îl indeplinească persoana aflată în acea circumstanță particulară, circumstanță pe care, la un anumit nivel, a ales-o în mod conştient şi voit, dar în funcție de care societatea îi evaluează, în final, comportamentul (Babbitt, 1997). Asta deoarece în cadrul societăţii o persoană poate fi considerată integră dacă acționează în baza aşteptărilor grupului social sau în baza unor scopuri considerate nobile de către grup. In lipsa unor valori prestabilite şi larg acceptate, nu putem vorbi de o condiție ideală a integrității. In ceea ce priveşte aşteptările grupului, se evaluează nu numai ceea ce face persoana, ci şi ceea ce nu face sau abstențiunea de a face ceva considerat imoral, ilicit, inacceptabil. Între altele, lipsa de integritate poate fi considerată exercitarea abuzivă a unui drept recunoscut la nivelul grupului, dar care prin maniera în care este folosit, lezează interesele altor persoane (Ignătescu, 2013).

Chiar şi când sunt discutate aspectele politice ale integrității, aceasta trebuie văzută ca un atribut personal, individual, chiar dacă este un concept cu implicații în sfera publică. Structurile sociale şi politice pot influența formarea integrității personale prin promovarea sau prin subminarea unor norme esențiale pentru practicarea integrităţii. Dacă integritatea este privită ca o virtute (Williams, 1973), instituțiile publice trebuie să promoveze integritatea sau cel puțin să dea posibilitatea ca integritatea personală să fie practicată ca o valoare. Dacă societatea este structurată în aşa fel încât să submineze încercările de a acționa conform principiilor sau a valorilor unei persoane, înseamnă că acea societate este antagonică ideii de integritate. Integritatea, ca şi practicare a virtuţii, este conectatată cu starea de bine a unei persoane, iar un sistem politic care nu sprijină comportamentele integre poate fi privit ca o amenințare la bunăstarea cetăţeanului. În această situaâie intervine alienarea, o stare de confuzie a indivizilor care sunt în conflict cu manifestarea, incompatibilă pentru ei, a societăţii sau a clasei politice. In acest caz, individul preia un rol care i se induce că ar fi ceea ce îşi doreşte.

\section{Concluzii}

Orice eforturi de a defini integritatea trebuie să aibă în vedere efectele contextului politico-social în care trăieşte individul respectiv. Societatea favorabilă integrităţii este aceea în care individul îşi poate dezvolta 
şi folosi capacitățile pentru reflexie critică, în care rolul autoasumat nu este contrastant cu cel impus (sau, cel puțin, nu este esențialmente divergent).

În concluzie, apreciem că integritatea nu poate fi apreciată dintr-un unghi strict personal, deoarece în cadrul societății, gândurile si valorile individuale sunt influențate sau influențabile, uneori chiar în afara controlului său şi fără să realizeze acest lucru. Integritatea personală în societate a devenit un hibrid între integritatea personală şi integritatea formală, normativă (chiar dacă ne referim la normativitate juridică sau doar la normativitate morală), deoarece pe baza contractului social (Rousseau, 1968) nu se mai poate vorbi de un individ total separat de stat şi societate, care să işi impună propriile valori, dar care să trăiască totuşi în societate.

\section{References}

Apostu, I. (2016). Infidelity - The imorality of the other. Revista Românească pentru Educație Multidimensională, 8(1), 7-10. doi:10.18662/rrem/2016.0801.01

Babbitt, S. E. (1997). Personal integrity, politics and moral imagination. In S. Brennan, T. Isaacs \& M. Milde (Eds.), A question of values: New Canadian perspectives on ethics and political philosophy (pp. 107-131). Amsterdam, Netherlands: Rodopi.

Calhoun, C. (1995). Standing for something. Journal of Pbilosophy, 92(5), 235-260. doi:10.2307/2940917

Ignătescu, C. (2013). Abuzul de drept [Abuse of rights]. Iaşi, Romania: Lumen.

Locke, J. (1996). An essay concerning buman understanding. Indianapolis, USA: Hackett Publishing Company.

Rousseau, J. J. (1968). The social contract. London, UK: Penguin Books.

Williams, B. (1973). Integrity. In J. J. C. Smart \& B. Williams (Eds.), Utilitarianism: For and against (pp. 108-117). New York, USA: Cambridge University Press. 